Staszel, A. (2019). Innowacje społeczne Polski oraz szanse ich rozwoju na tle innych państw. W: N. Laurisz, A. Stronczek (red.). Ekonomia Społeczna. Innowacje społeczne (s. 13-21). Kraków: Uniwersytet Ekonomiczny w Krakowie. https://doi.org/10.15678/ES.2019.1.02

\title{
Innowacje społeczne w Polsce oraz szanse ich rozwoju na tle innych państw
}

\begin{abstract}
Alicja Staszel
Streszczenie:

Innowacje społeczne są kwestią zainteresowania wszystkich państw rozwiniętych oraz tych, które dopiero się rozwijają. Władze państwa mają na celu dobro obywateli, dlatego starają się wprowadzać nowe rozwiązania, dzięki którym życie codziennie staje się prostsze. Aby nowe rozwiązanie można było uznać za innowację społeczną musi przejść ono przez wiele etapów i posiadać jej cechy charakterystyczne, które zostaną omówione w poniższym rozdziale. Celem opracowania jest zbadanie poziomu innowacji społecznych wdrażanych w Polsce oraz porównanie ich z innymi krajami. Metodą przeprowadzenia tego badania będzie przegląd literatury oraz analiz wykonanych przez Unię Europejską w tym zakresie. Każde państwo ma inny potencjał w zakresie wdrażania innowacji społecznych i w różnym stopniu go wykorzystuje. Rządzący powinni wspierać działania podmiotów, które wprowadzają takie pomysły, mając na uwadze dobro swojego kraju. W tym celu tworzone są różne programy, które pozwalają na uzyskanie wsparcia finansowego dla podmiotu, który pracuje nad innowacjami. Tworzone są one na poziomie krajowym, ale także ponadnarodowym (Unia Europejska). Przykłady tych programów (krajowych i unijnych) zostaną również opisane w poniższym tekście. Tekst pozwolił na sformułowanie wniosków dotyczących słabego poziomu rozwoju innowacji społecznych w Polsce, a także na ukazanie wielu szans, aby poziom ten znacznie poprawić.
\end{abstract}

Słowa kluczowe: innowacje; rozwój; czynniki rozwoju; poziom innowacji; programy społeczne Kody JEL: $\quad$ O35, P35

\section{Wprowadzenie}

Innowacje społeczne to wykorzystanie zasobów, które ma się w posiadaniu w celu rozwiązania problemów określonej społeczności. Działania takie mają charakter społeczny, zatem skutkują zmianami, które są korzystne zarówno dla jednostki, jak i całego społeczeństwa. Wśród korzyści, jakie są generowane przez innowacje społeczne można wymienić fakt, że służą do wzmocnienia relacji społecznych, a często również tworzą nowe więzi i powiązania. Następuje też wzrost możliwości samorozwoju w społeczeństwach, które mogą nauczyć się lepszego sposobu na wykorzystywanie posiadanych zasobów (Szczepańska, 2017, s. 220).

Temat innowacji społecznych jest istotny dla każdego człowieka, ponieważ dotyczą one bezpośrednio jego życia codziennego. Ważną sprawą jest, aby państwo dążyło do jak najwyższego ich stopnia zaawansowania, mając na celu dobro wszystkich obywateli. W niniejszym rozdziale skupiono się na poziomie oraz rodzajach innowacji społecznych Polski na tle innych krajów oraz możliwościach rozwinięcia ich w jeszcze większym stopniu. Pozwoli to na ocenę jakości wdrażanych innowacji dla mieszkańców kraju, a także perspektyw ich przyszłego rozwoju. 
Ulepszenia życia codziennego obywateli muszą posiadać charakterystyczne cechy, aby można je było nazwać „innowacjami społecznymi”. Wtedy stwarzają możliwości dla społeczeństwa do efektywnego działania. Innowacje społeczne powinny (Kwaśnicki, 2014, s. 28):

- być czymś nowym,

- być funkcjonalne od pomysłu aż do realizacji,

- być skuteczne,

- spełniać potrzeby społeczne,

- przyczyniać się do poprawy zdolności do działania społeczeństwa.

Głównym celem wdrażania nowych rozwiązań powinno być dobro całego społeczeństwa, a przede wszystkim podniesienie jakości życia. Nie można odnieść się tutaj tylko do wąskich grup społecznych.

Proces planowania innowacji społecznych przypomina planowanie programów, które stosowane są w marketingu społecznym. Na rysunku (Rysunek 1) przedstawiono poszczególne etapy takiego planowania.

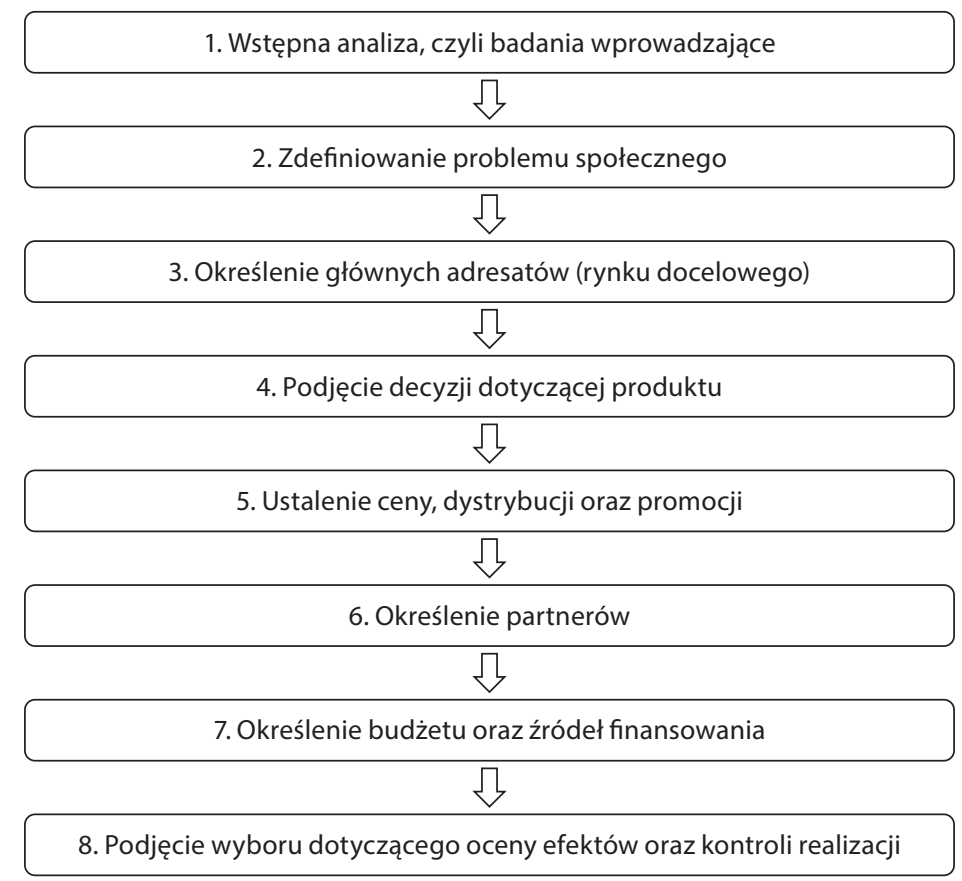

Rysunek 1. Planowanie innowacji społecznych

Źródło: opracowanie własne na podstawie: (Daszkiewicz, 2015, s. 2)

Najważniejszym etapem są badania wprowadzające, ponieważ umożliwiają one zdefiniowanie problemu społecznego. Aby wprowadzenie innowacji społecznych było efektywne, ten etap należy przeprowadzić ze szczególną starannością.

Według OECD innowacje społeczne to kategorie odnoszące się do koncepcji, pomysłów, strategii czy schematów organizacyjnych, które wprowadzane są w celu wzmocnienie roli społeczeństwa oraz poszerzenia jej, co jest odpowiedzią na pojawiające się potrzeby społeczne 
różnego rodzaju. Można wśród nich wyróżnić: pojawienie się nowych produktów i usług, nowych modeli organizacyjnych, nowych form instytucjonalnych, nowych ról oraz funkcji oraz nowych mechanizmów zarządzania. Dobrobyt społeczny powinien być przede wszystkim celem wprowadzania tego typu innowacji, a nie tylko konsekwencją (OECD, 2011, s. 13). Rodzaje innowacji społecznych przedstawiono w tabeli (Tabela 1).

\section{Tabela 1. Rodzaje innowacji społecznych}

\begin{tabular}{|l|l|}
\hline \multicolumn{1}{|c|}{ Rodzaj innowacji społecznych } & \multicolumn{1}{c|}{ Przykład } \\
\hline Nowy produkt & Pomoc dla osób z niepełnosprawnością (np. syntezatory głosu) \\
\hline Nowa usługa & Bankowość mobilna \\
\hline Nowy proces & $\begin{array}{l}\text { Crowdsourcing - proces przekazywania zadań przez organizację do szerokiej grupy osób, } \\
\text { często nawet bez ich identyfikacji }\end{array}$ \\
\hline Nowe rynki & Fair trade \\
\hline Nowe platformy & $\begin{array}{l}\text { Nowy model opieki nad osobami niepełnosprawnymi intelektualnie, które znajdują się } \\
\text { W „społecznej izolacji” }\end{array}$ \\
\hline Nowe formy organizacyjne & Przedsiębiorstwa społeczne \\
\hline Nowe modele biznesowe & Franczyza społeczna \\
\hline
\end{tabular}

Źródło: opracowanie własne na podstawie: (Wronka-Pośpiech, 2015, s. 129).

Innowacje społeczne dotyczą następujących obszarów (Nicholls i Murdock, 2012):

- transformacji społecznej (to przede wszystkim społeczeństwo obywatelskie w procesie przemian, jakie w nim zachodzą oraz ekonomia społeczna, a także przedsiębiorcy społeczni realizujący wzrost gospodarczy i integrację społeczną; biznes dotyczący zmian społecznych - społeczna odpowiedzialność biznesu; ważna jest także rola, jaką pełnią przedsiębiorstwa prowadzące kolejną falę innowacji oraz produktywności),

- model zarządzania organizacją (budowa strategii biznesowych, które obejmują zmiany w kapitale ludzkim, społecznym i instytucjonalnym, które poprawiają sprawność organizacyjną i konkurencyjność; restrukturyzacja organizacyjna, a także modernizacja stosunków przemysłowych i poprawa w zakresie zarządzania zasobami ludzkimi),

- przedsiębiorczość społeczna (dotyczy rozwoju nowych oraz innowacyjnych sposobów na pokonywanie trudnych wyzwań społecznych za pomocą zaangażowania przedsiębiorców będących „wrażliwymi społecznie”; takie przedsiębiorstwa to przede wszystkim firmy posiadające cele społeczne i przekazujące swoje nadwyżki na tego typu przedsięwzięcia),

- rozwój nowych produktów, programów oraz usług (muszą one zaspokajać potrzeby społeczne; są to innowacje, które mają miejsce w sektorze publicznym, a także świadczone usługi publiczne w przedsiębiorstwach zaangażowanych społecznie oraz organizacjach społeczeństwa obywatelskiego; są to także środki redystrybucji w oszczędności budżetowe państwa dobrobytu),

- model zarządzania, wzmacniania pozycji oraz zwiększania zdolności instytucji społecznych (dotyczy poprawy wzajemnych relacji pomiędzy instytucjami społecznymi, poprawy umiejętności, kompetencji oraz kapitału społecznego pośród podmiotów życia społecznego, którzy zaangażowani są w rozwój oraz realizację strategii i programów społecznych oraz gospodarczych). 
Unia Europejska wspiera rozwój innowacyjności poprzez wiele instrumentów finansowych, którymi są różnego rodzaju programy angażujące środki pieniężne w tego rodzaju inicjatywy. Wśród nich można wymienić (Kasprowicz i Murzyn, 2014, s. 139):

- Europejski Fundusz Społeczny,

- Europejski Fundusz Rozwoju Regionalnego,

- Programu Unii Europejskiej na rzecz przemian i innowacji społecznych,

- Europejski Fundusz Rolny na rzecz Rozwoju Obszarów Wiejskich,

- Horyzont 2020,

- Program ramowy na rzecz konkurencyjności przedsiębiorstw oraz małych i średnich przedsiębiorstw 2014-2020 COSME.

Istotną rolę we wprowadzaniu innowacji społecznych musi spełnić państwo, które powinno tworzyć optymalne warunki do wdrożenia nowych rozwiązań oraz zapewnić finansowanie takich inwestycji. Nowe rozwiązania są też finansowo wspierane przez podmioty, które je wdrażają. Wszystkie te podmioty tworzą pewną sieć, którą można nazwać „ekosystemem innowacji społecznych". Jej kreowanie w sposób aktywny należy do zadań rządu danego państwa (Dziembała, 2018, s. 151).

\section{Innowacje społeczne w Polsce}

Polska jest krajem rozwijającym się i posiada ogromny potencjał w zakresie innowacyjności, w tym innowacji społecznych. Jednak inną kwestią jest fakt, w jaki sposób wykorzystywane są te możliwości. W tym aspekcie nasz kraj nie osiąga dobrych wyników.

Na wykresie (Wykres 1) zaprezentowano sytuację Polski w zakresie innowacji w 2019 r. na tle innych państw.

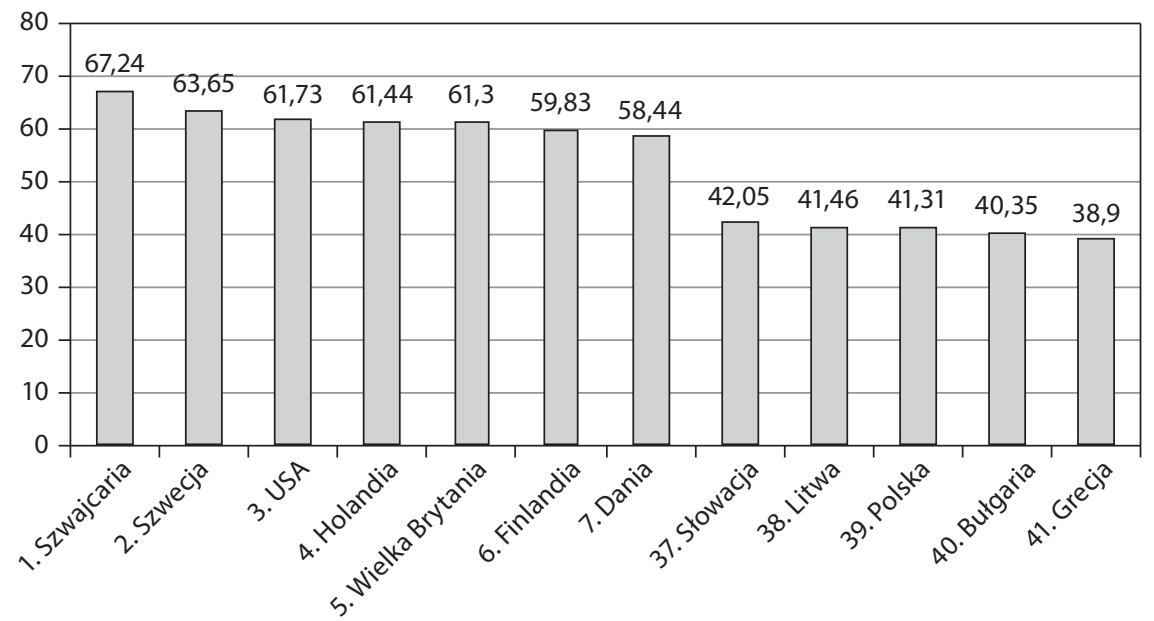

Wykres 1. Poziom innowacji w wybranych krajach w 2019 roku

Źródło: opracowanie własne na podstawie: (Dutta i in., 2019).

Z powyższego wykresu można wywnioskować, że poziom polskich innowacji społecznych kształtuje się na niskim poziomie (41,31 punktów w skali 0-100). Większość krajów europej- 
skich znajduje się na początku rankingu innowacyjności, natomiast nasze państwo zajmuje dopiero 39. miejsce. W czołówce innowacyjnych krajów znajduje się Szwajcaria, Szwecja oraz Stany Zjednoczone.

Na wykresie (Wykres 2) zaprezentowano poziom innowacji społecznych w wybranych krajach i w Polsce. Badania przeprowadzono w 2016 r.

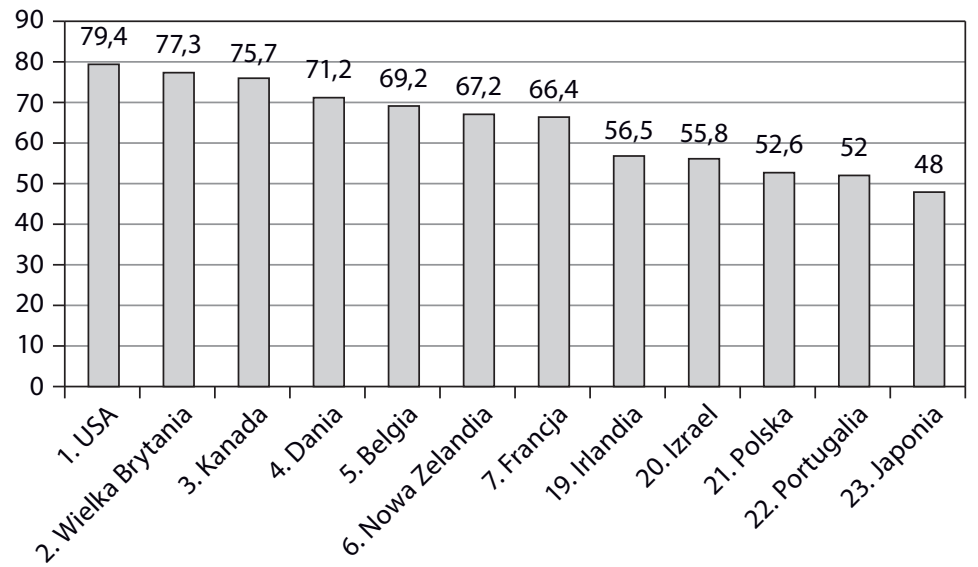

Wykres 2. Poziom innowacji społecznych w wybranych krajach w 2019 roku

Źródło: opracowanie własne na podstawie: (Old Problems, 2016).

W przypadku innowacji społecznych sytuacja Polski jest nieco lepsza, ponieważ zajmuje ona 21. miejsce (52,60 punktów w skali 0-100). Jednakże należy zauważyć, że jest to wynik dużo niższy od liderów w tej kategorii, którymi są Stany Zjednoczone, Wielka Brytania czy Kanada. Nasz kraj ma zatem długą drogę przed sobą w kwestii rozwijania innowacji społecznych na rzecz swoich obywateli.

Wskaźnik innowacji społecznych obejmuje następujące 4 aspekty (Dziembała, 2018, s. 152):

- ramy instytucjonalne oraz polityczne,

- dostępność finansowania,

- przedsiębiorczość,

- społeczeństwo obywatelskie.

Pierwszy z nich obejmuje politykę państwa dotyczącą istnienia innowacji społecznych, badań na rzecz tych innowacji, warunków prawnych w jakich działają społeczne przedsiębiorstwa, a także efektywność wdrażania reguł prawnych oraz działania politycznego. Drugi aspekt dotyczy dostępności finansowania innowacji społecznych przez rząd, łatwości otrzymania kredytu oraz całkowitych wydatków publicznych na cele społeczne.

Każde z krajów posiada inny potencjał we wdrażaniu innowacji społecznych. Stany Zjednoczone są liderem w tej kwestii. W tym państwie ważna jest rola sektora prywatnego we wspieraniu działań na rzecz społeczeństwa, ale kluczową rolę przypisać należy rządowi federalnemu. W tym kraju powstał Fundusz Innowacji Społecznych (Social Innovation Fund - SIF), który łączy środki prywatne oraz publiczne. Jego działania skupiają się przede wszystkim na możliwościach gospodarczych kraju, rozwoju młodzieży i zdrowej przyszłości obywateli (Dziembała, 2018, s. 153-154). 
Stany Zjednoczone są przykładem państwa, które znakomicie radzi sobie z wykorzystaniem swojego potencjału w zakresie wdrażania innowacji społecznych. Dobro obywateli jest jednym z ważniejszych celów dla rządu, dlatego tak mocno skupia on swoją uwagę na wprowadzaniu coraz to nowszych rozwiązań ułatwiających ich życie codzienne.

\section{Szansa Polski na wykorzystanie potencjału w zakresie innowacji społecznych}

Unia Europejska jest organizacją ponadnarodową, która chce pomóc krajom członkowskim w zakresie rozwijania innowacji społecznych. W tym celu tworzone są specjalne programy, o których wspomniano już wcześniej w tym rozdziale. Strategia Europa 2020: Unia innowacji zawiera istotne kwestie w zakresie wykorzystania innowacji w celu sprostania wszystkim wyzwaniom, przed jakimi stoi społeczeństwo. Pojawia się również wzmianka o europejskich partnerstwach innowacji, które mają służyć do rozwiązywania głównych problemów społecznych (Komisja Europejska, 2010).

W Polsce na rzecz innowacji społecznych również prowadzone są różne programy, m.in. wspierane przez Europejski Fundusz Społeczny poprzez Inicjatywę Wspólnotową Equal (lata 2004-2006). Rozwój działań na rzecz społeczeństwa finansowany był również przez Program Operacyjny Kapitał Ludzki (lata 2007-2013). Projekty te zawierały rozwiązania i narzędzia testowane w tych latach, a następnie rekomendowane do wykorzystywania na szeroką skalę (Wróblewska, 2016, s. 26).

Program Operacyjny Kapitał Ludzki (PO KL) skupiał się na różnorodnych obszarach społecznych. Wśród nich uwagę skupiono na poszczególnych zakresach:

1. Adaptacyjność. Celem była przede wszystkim poprawa przepływu informacji między przedsiębiorcami a naukowcami, wdrażanie projektów badawczo-rozwojowych, dopasowanie oferty naukowej dla uczących się, ułatwienie dostępu do wsparcia dla MŚP, zwiększenie poziomu wykorzystania potencjału pracowników w wieku 50+, zdobywanie lepszych kwalifikacji przez pracowników MŚP.

2. Edukacja. W tym zakresie główny cel to poprawa wyników uczniów w zakresie przedmiotów przyrodniczo-matematycznych, kreatywności uczniów, zdobycie informacji na temat potrzeb panujących na rynku pracy, poprawa sytuacji trudnej młodzieży oraz zwiększenie zainteresowania w tematyce kształcenia ustawicznego.

3. Zatrudnienie i integracja społeczna. Celem było zwiększenie skuteczności działania instytucji rynku pracy, stworzenie narzędzi, które mają na celu wsparcie osób o najtrudniejszej sytuacji na ryku pracy, odpowiednie przygotowanie absolwentów do radzenia sobie na rynku pracy oraz poprawa zatrudnienia wśród osób niepełnosprawnych.

4. Dobre rządzenie. W tym zakresie główne cele to poprawa efektywności oceniania skutków regulacji, podniesienie efektywności systemów zarządzania, zwiększenie profesjonalizacji usług społecznych.

Na lata 2014-2020 zaplanowano realizację nowego programu wspierającego innowacje społeczne w Polsce - Program Operacyjny Wiedza Edukacja Rozwój 2014-2020. Priorytetem dla tego programu są przede wszystkim innowacje społeczne, a także współpraca ponadnarodowa. Nowe rozwiązania, jakie zostaną zaplanowane w ramach tego programu, muszą być możliwe do zastosowania na terenie całego kraju. Główny cel zawarty w tym programie to "Zwiększenie wykorzystania innowacji społecznych na rzecz poprawy skuteczności wybranych aspektów polityk publicznych w obszarze oddziaływania Europejskiego Funduszu Spo- 
łecznego". Nowe rozwiązania dotyczą przede wszystkim zatrudnienia i zdrowia. Przewidziane zostały dwa schematy wdrażania innowacji społecznych (Dziembała, 2018, s. 157):

Mikro-innowacje: w ich ramach znajdują się projekty grantowe, które związane są przede wszystkim z rozwijaniem pomysłów innowacyjnych od zalążka, testowaniem ich, podejmowaniem określonych działań, aby można było je włączyć do polityk, a w konsekwencji upowszechnić je w szerszym zakresie. Wspierane zostaną osoby indywidualne, małe grupy, które przedstawią pomysł innowacyjny. Są to tzw. inkubatorzy pomysłów.

Makro-innowacje: ich główny cel to wprowadzanie nowych pomysłów i zmian, zarówno do polityki, jak i do codziennego życia, poprzez podmioty, które posiadają ogromny potencjał - określa się ich jako policy innovation. Istotne w tym rodzaju innowacji jest zwracanie uwagi na rezultaty oraz na wprowadzanie zmian innowacyjnych, które były testowane. Jest to możliwość przedstawienia pomysłu o większym poziomie ryzyka, który jest nowatorski i doskonale wykorzystuje potencjał społeczny.

Program ten ma na celu również aktywizację podmiotów, które związane są z projektami innowacyjnymi objętymi wsparciem z Europejskiego Funduszu Społecznego.

\section{Polskie miasta a innowacje społeczne}

Innowacje społeczne w miastach skutkują wzrostem komfortu życia na jego obszarze. Mieszkańcy miast coraz częściej biorą czynny udział w ich zarządzaniu, aby wspólnie tworzyć innowacyjne miasta przyszłości. Coraz częściej można obserwować powstawanie świetlic, kafejek internetowych, różnego rodzaju klubów (m.in. Klub Malucha, Klub Seniora, Klub Młodych). Takie miejsca zrzeszają konkretne grupy mieszkańców, którzy w miłej atmosferze spędzają wspólnie wolny czas. Jest to bardzo korzystne w przypadku samotnych starszych osób, które mają szansę z kimś porozmawiać czy zaprzyjaźnić się. Spotkania dla młodzieży mogą pomóc w ich rozwoju, polepszyć ich umiejętności nawiązywania kontaktów, rozwijać zainteresowania. W przypadku trudnej młodzieży może to pozytywnie wpłynąć na zmiany dokonujące się w ich życiu. Młode osoby mogą w ten sposób wzajemnie sobie pomagać w nauce oraz trudnych chwilach. Powstające świetlice umożliwiają małym dzieciom wspólną zabawę z rówieśnikami, co wpływa na ich rozwój oraz pomaga w zdobywaniu przyjaciół. Powstają zazwyczaj na jednym osiedlu i zrzeszają maluchów z okolicznych bloków.

Inną innowacją społeczną jest „bank czasu”, którego działanie opiera się o wymianę wzajemnej pomocy wśród mieszkańców. Każda osoba posiada swoje konto i gdy pomoże komuś, poświęcając swój czas, na jej konto wpływają "dolarogodziny”. Może nimi płacić w sytuacji, gdy pomoc będzie potrzebna tej właśnie osobie. Pomaga wtedy inny członek banku. Jest to pomoc przede wszystkim w: wyprowadzaniu psów, nauce, robieniu zakupów, naprawie sprzętów, czy opiece nad dziećmi lub osobami starszymi. Większość takich banków została założona przez organizacje pozarządowe.

Przykładem innowacji społecznych w miastach może być również kooperatywa spożywcza. W jej ramach mieszkańcom dostarczana jest żywność ekologiczna. Takie projekty często nazywane są rolnictwem wspieranym poprzez społeczność (RWS). Dostarczane produkty pochodzą od najbliższych ekologicznych rolników. Członkowie takiej kooperatywy wnoszą określoną składkę oraz organizują dostawę żywności, mają kontakt z dostawcami, a także weryfikują sposób uprawy oraz produkcji. W zamian otrzymują zdrową żywność w niskich cenach. Członkowie kooperatyw to zazwyczaj młodzi, wykształceni ludzie mieszkający w dużych miastach, którzy są świadomymi konsumentami zaangażowanymi społecznie. 
Innowacją społeczną można nazwać również tzw. carpooling, czyli wzajemne podwożenie się. Jest to próba walki z ogromnym problemem polskich miast, jakim są korki. Inicjatywa ta łączy ze sobą osoby podróżujące w tym samym kierunku każdego dnia (do szkoły, do pracy). Zmniejsza to natężenie ruchu w mieście, korki, obniża koszty dojazdu oraz zmniejsza zanieczyszczenie powietrza, co jest teraz bardzo istotną kwestią w miastach.

\section{Podsumowanie}

Temat innowacji społecznych jest bliski każdemu pojedynczemu człowiekowi i dotyczy jego życia codziennego. Z tego powodu uważany jest za bardzo istotny w podjętym rozdziale oraz wielu innych pracach naukowych. Państwo powinno mieć na celu rozwijanie innowacji w jak największym stopniu, aby uprościć codzienne czynności każdego z nas. Polska pod tym względem wypada bardzo przeciętnie na tle innych krajów. Jako kraj rozwijający się, Polska posiada ogromny potencjał we wdrażaniu innowacyjnych rozwiązań służących społeczeństwu. Rządzący powinni mieć tego świadomość i dążyć do jeszcze większego ich rozwoju. Wspieranie innowacji społecznych łatwiejsze jest dzięki różnym programom społecznym prowadzonym m.in. przez Unię Europejską. Władze naszego kraju muszą zatem nauczyć się, jak z nich właściwie korzystać, aby poprawić swoją pozycję w rankingu najbardziej innowacyjnych państw. Powinny również zostać przeprowadzone badania, jakie potrzeby społeczne są zgłaszane obecnie przez obywateli kraju, a następnie decyzje władz powinny być dostosowane do tych potrzeb.

\section{Literatura}

Daszkiewicz, M. (2015). Innowacje społeczne w kreowaniu atrakcyjności miast. Wrocław: Uniwersytet Ekonomiczny we Wrocławiu.

Dutta, S., Lanvin, B., Wunsch-Vincent, S. (red.). (2019). The Global Innovation Index. Cornell University, INSEAD, WIPO. Pobrane z: www.globalinnovationindex.org/gii-2019-report (dostęp: 25.05.2019).

Dziembała, M. (2018). Wspieranie innowacji społecznych na rzecz zapewnienia spójności - doświadczenia wybranych krajów. Nierówności Społeczne a Wzrost Gospodarczy, 55, 149-161.

Kasprowicz, D., Murzyn, D. (2014). Innowacje społeczne - skuteczna odpowiedź na kryzys gospodarczy w Unii Europejskiej?. Prace Komisji Geografii Przemysłu Polskiego Towarzystwa Geograficznego, 28, 129-143.

Komisja Europejska (2010). Projekt przewodni strategii Europa 2020: Unia innowacji. Komunikat Komisji do Parlamentu Europejskiego, Rady, Europejskiego Komitetu Ekonomiczno-Społecznego oraz Komitetu Regionów, COM (2010) 546.

Kwaśnicki, W. (2014). Jak wspierać rozwój innowacji społecznych. W: A. Olejniczuk-Merta (red.). Innowacje społeczne od idei do upowszechniania efektu (s. 27-43). Warszawa: Instytut Badań Rynku, Konsumpcji i Koniunktur.

Nicholls, A., Murdock, A. (2012). Social innovation: blurring boundaries to reconfigure markets. Hampshire-New York: Palgrave Macmillan, Handmill, Basinstoke.

OECD (2011). Fostering Innovation to Address Social Challenges. Workshop Proceedings. OECD Innovation Strategy.

Old Problems, New Solutions: Measuring the capacity for social innovation across the world (2016). The Economist Intelligence Unit. Pobrane z: www.essmart-global.com/wp-content/uploads/2016/12/2016.09.29-Economist-Social-Innovation-Index.pdf (dostęp: 25.05.2019).

Szczepańska, M. (2017). Innowacje społeczne w polskich miastach. W: A. Kaszkur, A. Laska (red.). Innowacyjność w warunkach współczesnych miast (s. 219-228). Bydgoszcz: Wydawnictwo Uniwersytetu Kazimierza Wielkiego.

Wronka-Pośpiech, M. (2015). Innowacje społeczne - pojęcie i znaczenie. Zeszyty Naukowe Uniwersytetu Ekonomicznego w Katowicach, 212, 124-136.

Wróblewska, A. (2016). Innowacje społeczne. Fundusze Europejskie w Polsce. Biuletyn Informacyjny, 39 , 26-27. 


\title{
Polish social innovations and opportunities for their development in comparison to other countries
}

Summary: Social innovation gain interest in both developed and developing countries. To increase the well-being of the citizens, policy makers try to introduce new solutions, improving the quality of everyday life. Whether these solutions can be labelled social innovations, they need to undergo certain stages and meet specific criteria, which will be discussed in this chapter. The aim of the chapter is to evaluate the level of social innovation in Poland and to compare it with the levels in other European countries. The method used in this study is a review of literature as well as EU's analyses in this area. Each country has different potential in terms of introducing social innovations and uses that potential to a different degree. Authorities should support the activities of entities that introduce such ideas, taking the interests of the country into consideration. In order to achieve that, different financial support programs are launched. They are created on a national as well as supranational level (EU). Examples of such programs will be discussed in the chapter. The chapter will allow to formulate conclusions regarding the respectively low level of social innovation in Poland, as well as to present opportunities for enhanced growth in this area.

Keywords: innovations; development; development factors; level of innovation; social programs JEL codes: O35, P35

\section{Informacje 0 autorze}

\author{
Alicja Staszel \\ Agencja Artystyczna GAP \\ ul. ks. bp. Wł. Bandurskiego 58/11, 30-050 Kraków \\ e-mail: ala.staszel96@gmail.com
}

\section{Prawa autorskie i licencja / Copyright and License}

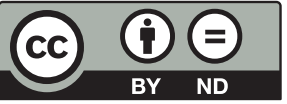

Publikacja na licencji Creative Commons Uznanie autorstwa Użycie niekomercyjne - Bez utworów zależnych 4.0 Międzynarodowe (CC BY-ND 4.0) http://creativecommons.org/licenses/by-nc-nd/4.0/deed/pl

This work is published under the terms of the Creative Commons Attribution - NoDerivetives International (CC BY-ND 4.0) License http://creativecommons.org/licenses/by-nc-nd/4.0

Wydane przez Uniwersytet Ekonomiczny w Krakowie. Małopolska Szkoła Administracji Publicznej Published by Cracow University of Economics - Krakow, Poland. Małopolska School of Public Administration of the Cracow University of Economics 